\title{
Experiences with the Urbanisation of Slums: Management and Intervention Models
}

\author{
Adauto Lucio Cardoso, Angela Maria Gabriella Rossi \\ Federal University of Rio de Janeiro (UFRJ) \\ cardoso@ippur.ufrj.br,gabriella.rossi@poli.ufrj.br \\ Brazil
}

\section{Introduction}

Brazilian municipalities have accumulated a substantial amount of administrative and technical knowledge about the methods and alternatives for offering technical assistance in precarious settlements. So far, however, that experience is still fragmented. It is thus necessary to identify and consider both the successes and the failures that have been made.

A main controversy on the topic involves the question of whether to establish a national policy, managed centrally by the Ministry of Cities (Ministério das Cidades), to establish technical and environmental quality criteria in the activities to be carried out under an Urban Plan, or to not have such criteria and instead determine the criteria for each individual case at the local level. Considering that the resources used for such projects are public and federal, and that the responsibility for implementing these plans lies with the responsible body, there is a strong argument that some kind of control should be established so that the managing party can be made accountable for the results. This would require comparing the results with some established criteria.

Brazilian historical experience does not recommend the adoption of general models or patterns for the interventions, due to the risk of creating insurmountable regulatory barriers and recognising that the residents of the precarious settlements have a right to housing. The regional inequalities and the different situations that characterise the various existing settlements reinforce the difficulty of establishing universal standards, which may result in criteria that are not adequately suited to local conditions and needs.

Another argument used to promote the need for standards is related to the planners' aesthetic and ideological tendencies, which are marked by rationalism and the modernist functionalism that do not recognise the environmental and aesthetic virtues of these settlements.

A radical opinion is that interventions in the slums and other precarious settlements should interfere as little as possible with their urban structure, respecting the physical characteristics of the settlement and the right of people to remain in it, and limiting radical changes to those settlements such that the only changes are necessary to solve serious problems or to provide growth or extensions of roads to ensure accessibility. This has been the decision of many municipal programmes that have dealt with the urbanisation of slums. 
Other arguments can be considered as well. One of these opinions considers the problem of violence in the slums and the importance of restructuring the spaces as a way to ensure democracy and public use.

The ways of structuring the precarious settlements do not necessarily constitute a choice or "a construction project" but, rather, an extremely desperate need for which there are no other options at hand.

Another important point concerns the establishment of "minimum standards". The debate initiated by the rationalism in architecture and engineering at the beginning of the twentieth century can be seen from two viewpoints. On one side, by proposing minimum standards, regulatory controls on the market can be established to avoid the diseases and epidemics often present due to "non-hygienic" houses. This was meant to establish the principles of a new type of citizenship, guided not only by personal and political rights but also by social rights. On the other side, it was considered by some to be a mechanism of control and domestication of poor people in order to guarantee the dominion of capital.

The principles of rationalism made tabula rasa of cultural realities and needs, creating housing designs that followed the mandates of rationalisation of space and buildings, on one side, and the cultural options of the middle classes, seen as universal needs, on the other. The inadequacy of that model for the care of the real needs of the grassroots was emphasised by the criticism of John Turner (Turner, 1972) and, in the case of Brazil, Carlos Nelson Ferreira dos Santos (Santos, 1977). An extreme example was the removal of slums that occurred during the military dictatorship.

The problem is that the criticism - necessary and appropriate - of modern rationalism obscures its positive aspects, particularly the idea that each citizen has the right to decent housing: healthy, safe, functional, and in a sustainable environment, with adequate access to public spaces, infrastructure, and collective equipment. Certainly, nowadays everyone agrees with this. The question is how to make the concept of decent housing operational in programs of urbanisation of precarious settlements.

Recent Brazilian experiences have shown great progress in several areas, including the development of methods of intervention, experienced technical teams, diagnosis techniques, and improved designs. A disparity concerns the degree of intervention to reduce population density, either with structural improvements in the settlements or by relocating homes in the situation of extreme hazards.

Some projects have set certain standards, such as for the width of streets, minimum lot sizes, the maximum length of a street, the distance between steps in staircases, and so on. Other interventions have been limited to solve more basic issues: areas of risk, minimum accessibility, common areas, infrastructure, and some collective equipment. There are, in these cases, situations of the consolidation of homes in extremely precarious situations: houses made with improvised materials, buildings at risk of collapse, narrow alleys between tall buildings where the sun never penetrates, flooded land, or blocks with internal houses where it is not possible to open windows without being completely surrounded by other buildings.

Based on the above arguments, it is recommended to work towards the establishment of flexible standards, adaptable to regional conditions, that are gradual and generic enough to avoid impediments to the process of regularisation and that are able to respond at the same time to the legitimate need of respecting differences and ensuring decent housing. 
This chapter seeks to identify the basic points and some very general criteria that could be used as parameters for intervention and design.

The first consideration relates to the type of intervention. The accumulated experience allows us to identify 3 basic types: urbanisation, re-urbanisation, and removal. Urbanisation means that the intervention does not modify the structure of the settlement, but rather only the building infrastructure and paving. It is the appropriate intervention for cases where the densities are lower and the design of settlements is compatible with existing standards . Reurbanisation includes interventions that, because of the inadequacy of the site, completely replace the structure of the settlement by dividing and relocating families in the same area. Removal means the removal of the population and their resettlement in another area. This may be the case when the settlement occupies an at-risk area or an area of environmental preservation of "inestimable ecological value." In practice, several interventions make use of all 3 alternatives, relocating a part of the settlement and removing a portion of the population. The point here is what the main characteristic of the intervention is.

The choice among the 3 alternatives depends on the conditions of the site and the minimum standards that are or are not used. The adoption of standards often involves the need to lower the population density, which involves the division of lots and, in some cases, the removal process.

Another way to classify the interventions relates to their scope : they can be complete or partial. That is, they can be related either to a part of the settlement (partial) or to the whole settlement (complete). Partial interventions have been historically done in slums and in lots, possibly because of clientelistic political practices or in emergency situations. The problem with complete interventions is the need for a significant amount of resources, covering the settlement as a whole, which limits action in only a few settlements. An alternative to this problem has been the adoption of gradual planned interventions, in which partial interventions are linked to a global plan of action and a technically consistent sequence of actions. Gradual planned interventions may be adopted in cases where the local government provides assistance to several settlements at the same time, which is only financially feasible by extending the time of the finalisation of services.

Another important distinction concerns the components of the intervention, allowing its characterisation as sectoral or integrated. In general, integrated projects are those that include the social dimension in addition to the physical-urban and environmental dimensions. The components of an integrated project vary according to the specific needs of the settlement and also with the available budgetary possibilities.

In general, there is a consensus between technicians and managers that complete (or gradual planned) interventions and integrated projects have greater effectiveness than partial or sectoral interventions. It is necessary, however, to remember that the adoption of one kind or another depends on the needs of each settlement and also on the available resources.

In this sense, it is recommended that the interventions should be mainly complete or gradual planned and integrated, including popular participation, land regularisation, physical-urban, social and environmental intervention, and post-occupation measures, highlighting urban regularisation. It is important to note, however, that this general recommendation should be adapted to the conditions of financing and to local needs.

For each settlement, a plan of intervention is developed based on the physical-urban, environmental, and social diagnosis. The plan must include priorities and stages of intervention, considering the technical and social needs and the available financial 
resources. It is essential that the plan of intervention must also consider the environmental conditions, taking as reference, for example, the elements of the urban structure. Considering the difficulties of understanding and adequately controlling all the elements necessary for the implementation of a feasible executive project, the intervention plan must include a basic project that provides the detail and the generic elements of the construction but ensuring a degree of flexibility.

Regarding quality standards, the elements that will be included as components of the integrated project should be considered. A study done by the Instituto de Pesquisas Tecnológicas - IPT, Denaldi (2003) defined 3 levels to describe the types of intervention according to physical-urban quality standards:

- Minimum Standard: includes networks of water, sewage, energy, drainage, solutions for the collection of waste (direct or indirect), accessibility, treatment of areas of risk (which may involve relocation or division of lots), and land regularisation;

- Intermediate Standard: in addition to the above, this also includes urban equipment, road systems, and environmental interventions in order to address environmental problems and urban structure;

- High Standard: in addition to the above, this includes adequacy of population density, division of lots, rehabilitation or reconstruction of housing units in insecure and unsanitary situations, and an adequate road system with minimum parameters of width of streets, ensuring accessibility to all homes with pedestrian ways.

The choice between these standards depends, first, on the conditions found in the settlements and local needs. In some cases, it is not required to update the road system or to lower the population density. In general, in the context of slums, the choice depends on how to solve the equation limited resources vs. decent housing. Simulations developed by IPT for the intervention of urbanisation in a slum situated on the banks of the Represa Guarapiranga (São Paulo) showed costs ranging between R\$2,300.00 and R \$ 26,500.00, depending on the alternative to be used. Evaluating several intervention projects in the area of the Guarapiranga, the IPT found costs ranged from $\mathrm{R} \$ 4,000.00$ to $\mathrm{R} \$ 11,000.00$ per family. One of the conclusions of this study was that the adoption of different standards (in terms of average density, lots, and road system) generated cost differences averaging around $30 \%$, considering that these are slums in the same context and under the same program. Thus, considering the scarcity of resources, the adoption of higher standards implies a higher cost, which results in being able to deal with a smaller number of settlements.

Another issue to be considered for the choice of standards is the local culture and the historical ownership of land. In this sense, some cities have far fewer problems with population density than cities like Rio de Janeiro and São Paulo, which are characterised by the scarcity of land. This element points toward a regional differentiation of patterns.

A central element to be considered is the popular participation in all spheres of deliberation. It is crucial that, in addition to the forums to be established through the creation of Municipal and State City Councils, it is important to create forums for the participation and social control of operations involving the groups directly affected. In this respect, interventions must be accompanied by commissions or committees composed of representatives chosen freely by the communities, which must be involved from the stage of drafting the plan of intervention until the post-occupation.

Intervention projects are developed to enable broad understanding by the population, even considering the different alternatives with respect to the adoption of certain quality 
standards and their impact on cost and the final quality of the project. In addition, in terms of monitoring, it is essential that the local committee monitors the implementation schedule and oversees the development and quality of services, with the authority to stop any actions involving a waste of resources or misuse of the project. In the final evaluation of the intervention, a separate report should be prepared by the local commission.

One of the essential elements of the integrated project is the social component, which involves the support for children and youth, generation of income, job training, and so on. For a better result, it is crucial to develop a project that take into account the needs and potentials of the community. Besides the social-economic data, which allows portraying the lives of families, it is important to assess the social-political conditions of the community, identifying resources and leadership through the use of participatory methodologies.

The social project has to be developed by a qualified team, integrated with the team that focuses on the physical-urban aspects, in order to solve problems of relationships with the community that usually arise in the course of the intervention. The social project must come before the physical design and should remain after the end of construction as an important part of the post-occupation activities.

Experience has shown that the post-occupation period is essential to ensure the objective of integrating the regularised settlements into the city. The post-occupation activities comprise the permanent social project, training courses, and generating income, as well as other activities related to the physical and urban dimension.

An important element is to check the suitability of the proposed solutions to the needs of the residents in the new context, as well as the quality of the work and the proper functioning of the infrastructure and equipment installed. In that sense, the post-occupancy evaluation is an important instrument for measuring the compatibility of solutions able to correct the problems, and it produces important data to guide new operations.

Another key element is the establishment of a pattern of urban control, defined from the existing situation during the project and after its conclusion, which is widely discussed and negotiated with the population. It must be considered that there are often informal practices, and it is slow and intensive work to create awareness of the importance of urban rules that represent limitations on individual actions. It is essential that these rules are simple, setting the spaces for public use and establishing some control of population density.

With regularisation and urbanisation, the costs of housing can rise, particularly those relating to taxes and tariffs of the concessionaires of public services. Special conditions and reduced tariffs should be negotiated for the population. The Statute of the City (Estatuto das Cidades) provides for the use of lower tariffs, which may also be included in the Master Plan or in specific legislation. In the case of services controlled by the state or private companies, the solution often requires extensive negotiations that, if mediated by the municipal government, will have more chances to be successful (Bassul, 2005).

\section{Some Experiences of Slums Upgrading}

Some of the precarious settlements that proliferate in large and medium-sized Brazilian cities have been the focus of urbanisation projects, which have been based on different models according to the region and to the public administration which manage them.

This part of the chapter shows the results of a recent two-year study done by four Brazilian Universities and financed by Financiadora de Estudos e Projetos - FINEP, of the Ministério 
da Ciência e Tecnologia. The research described and analysed several experiences that took place in four Brazilian states: São Paulo, Rio de Janeiro, Minas Gerais, and Bahia. Table 1 shows the analysed case studies.

\begin{tabular}{|c|c|c|c|}
\hline State & Program & $\begin{array}{c}\text { Name of the Case } \\
\text { Studies }\end{array}$ & $\begin{array}{l}\text { Public Institution } \\
\text { that promoted the } \\
\text { Intervention }\end{array}$ \\
\hline \multirow{3}{*}{$\begin{array}{l}\text { SÃO PAULO } \\
\text { (SP) }\end{array}$} & \multirow{2}{*}{$\begin{array}{c}\text { Saneamento } \\
\text { Ambiental da Bacia } \\
\text { do Guarapiranga }\end{array}$} & Sete de Setembro & \multirow{2}{*}{$\begin{array}{c}\text { Prefeitura Municipal } \\
\text { de São Paulo }\end{array}$} \\
\hline & & $\begin{array}{c}\text { Parque Amélia Santa } \\
\text { Margarida }\end{array}$ & \\
\hline & Urbanização Integral & Parque Capuava & $\begin{array}{c}\text { Prefeitura de Santo } \\
\text { André }\end{array}$ \\
\hline \multirow{3}{*}{$\begin{array}{l}\text { RIO DE JANEIRO } \\
(\mathrm{RJ})\end{array}$} & \multirow{3}{*}{$\begin{array}{l}\text { Favela-Bairro (Conde } \\
\text { \& Magalhães, 2004) }\end{array}$} & $\begin{array}{c}\text { Morro da } \\
\text { Providência } \\
\end{array}$ & \multirow{3}{*}{$\begin{array}{c}\text { Prefeitura da Cidade } \\
\text { do Rio de Janeiro }\end{array}$} \\
\hline & & Vila Mangueiral & \\
\hline & & Vigário Geral & \\
\hline \multirow{3}{*}{$\begin{array}{l}\text { MINAS GERAIS } \\
(\mathrm{MG})\end{array}$} & \multirow{2}{*}{$\begin{array}{l}\text { Plano Global } \\
\text { Específico } \\
\text { (URBEL, 2002) }\end{array}$} & $\begin{array}{c}\text { Vila Senhor dos } \\
\text { Passos }\end{array}$ & \multirow{2}{*}{$\begin{array}{c}\text { Companhia } \\
\text { Urbanizadora de } \\
\text { Belo Horizonte } \\
\text { URBEL }\end{array}$} \\
\hline & & $\begin{array}{l}\text { Vila Nossa Senhora } \\
\text { do Rosário }\end{array}$ & \\
\hline & - & $\begin{array}{c}\text { Bairro Córrego da } \\
\text { Ilha }\end{array}$ & Prefeitura de Sabará \\
\hline \multirow{3}{*}{$\begin{array}{l}\text { BAHIA } \\
\text { (BA) }\end{array}$} & \multirow{3}{*}{ Ribeira Azul } & Group I & \multirow{3}{*}{$\begin{array}{c}\text { Companhia de } \\
\text { Desenvolvimento } \\
\text { Urbano do Estado da } \\
\text { Bahia CONDER }\end{array}$} \\
\hline & & Group II & \\
\hline & & Group III & \\
\hline
\end{tabular}

Table 1. Case Studies (FINEP, 2007)

The results of the research are divided into three groups:

- analysis of the costs of urbanisation (Lareau, 2005);

- analysis of the Index of Environmental Health of Urbanised Slums (Almeida, 1999, and Abiko \& Almeida, 2000);

- analysis of the post-occupancy

The case studies from São Paulo are:

- COMUNIDADE SETE DE SETEMBRO(Fig. 1): situated in the São Bernardo basin, at the right margin of the Bacia do Guarapiranga. The community started occupying a municipal public area in 1970. The area suffered from erosion and floods. The intervention project began in October 1994 and concluded in January 1996.

- PARQUE AMÉLIA SANTA MARGARIDA (Fig. 2): situated in the Guavirutuba basin, at the left margin of the Bacia do Guarapiranga. The community occupies a municipal public area that has slopes between $20 \%$ and $30 \%$. The intervention began in January 1998 and concluded in August 1999.

- NÚCLEO HABITACIONAL PARQUE CAPUAVA (Fig. 3): situated in the extreme northeast of the Municipality of Santo André, in the Metropolitan Region of São Paulo. The area has 30\% slopes and the construction was not concluded as of 2005. 

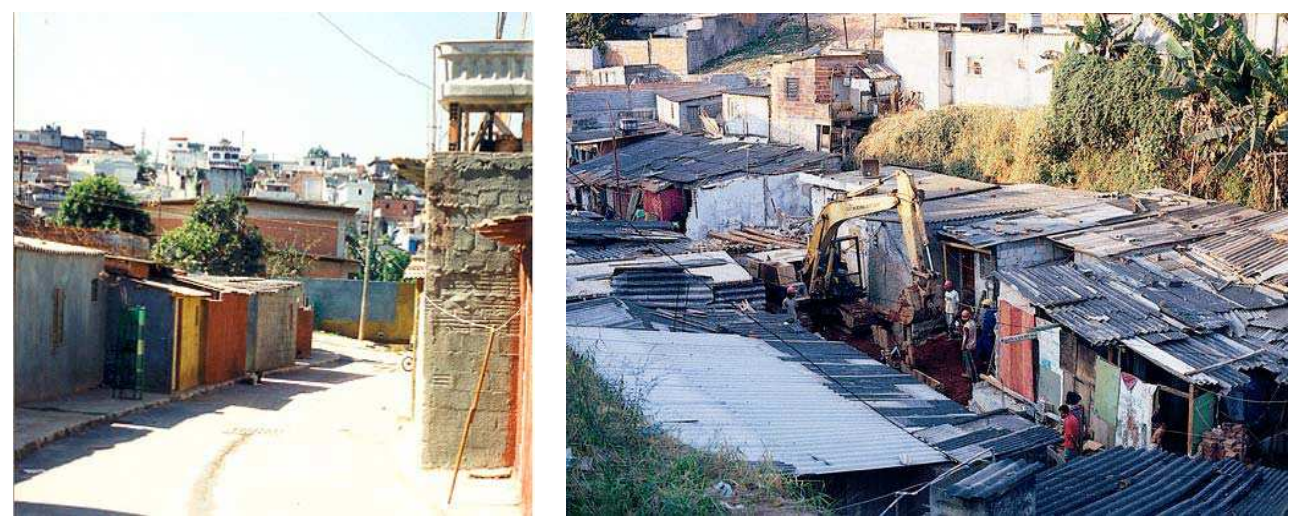

Fig. 1 and 2. Comunidade Sete de Setembro, and Parque Santa Améllia Santa Margarida
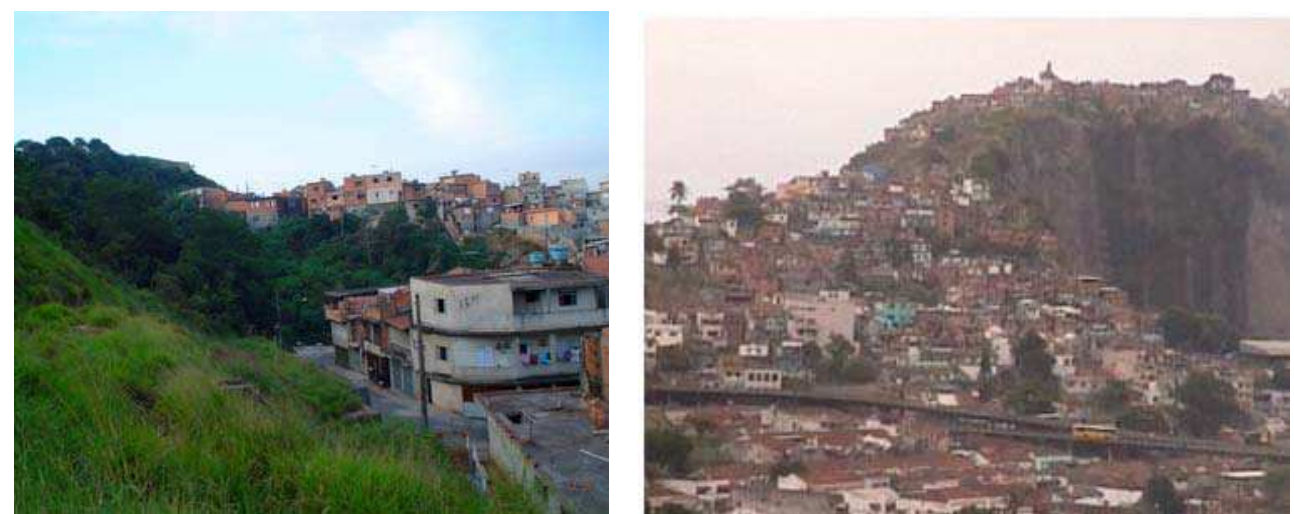

Fig. 3 and 4. Núcleo Habitacional Parque Capuava (SP), and Morro da Providência (RJ)

The case studies from Rio de Janeiro are:

- MORRO DA PROVIDÊNCIA (Fig. 4): situated on a hill and occupies the top and the north and south slopes. The area has 6,000 inhabitants and an area of $94,000 \mathrm{~m}^{2}$. The occupation dates from the end of the nineteenth century.

- VILA MANGUEIRAL (Fig. 5): situated in the west, in Campo Grande, at the margin of a river. It has 5,200 inhabitants and an area of 92,018 $\mathrm{m}^{2}$.

- VIGÁRIO GERAL (Fig. 6): the entire area was, until the 1930s, a large farm that was divided into small communities. It has 6,804 inhabitants and an area of 211,956 $\mathrm{m}^{2}$.

The case studies from Minas Gerais are:

- VILA NOSSA SENHORA DO ROSÁRIO (Fig. 7): situated in the eastern region of the Municipality of Belo Horizonte. Occupation began in 1940.

- VILA SENHOR DOS PASSOS (Fig. 8): the occupation of this area began in the 1940s and 1950s, and the slopes are as steep as $40 \%$.

- BAIRRO CÓRREGO DA ILHA (Fig. 9): situated on a slope in the Municipality of Sabará. The intervention is partially complete and started in the 1980s through self-help processes. 

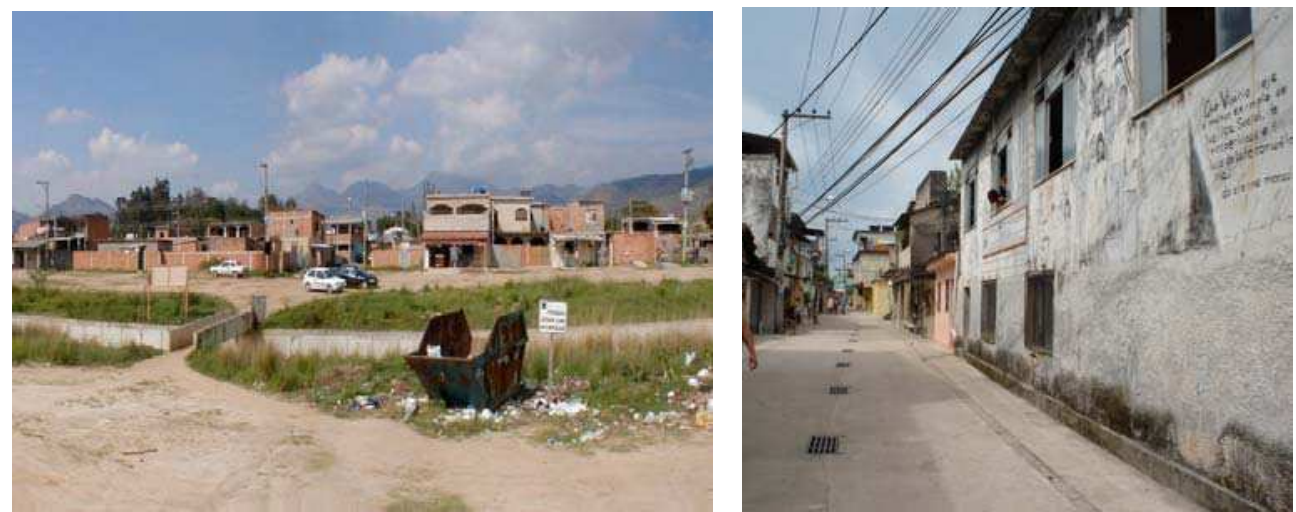

Fig. 5 and 6. Vila Mangueiral, and Vigário Geral
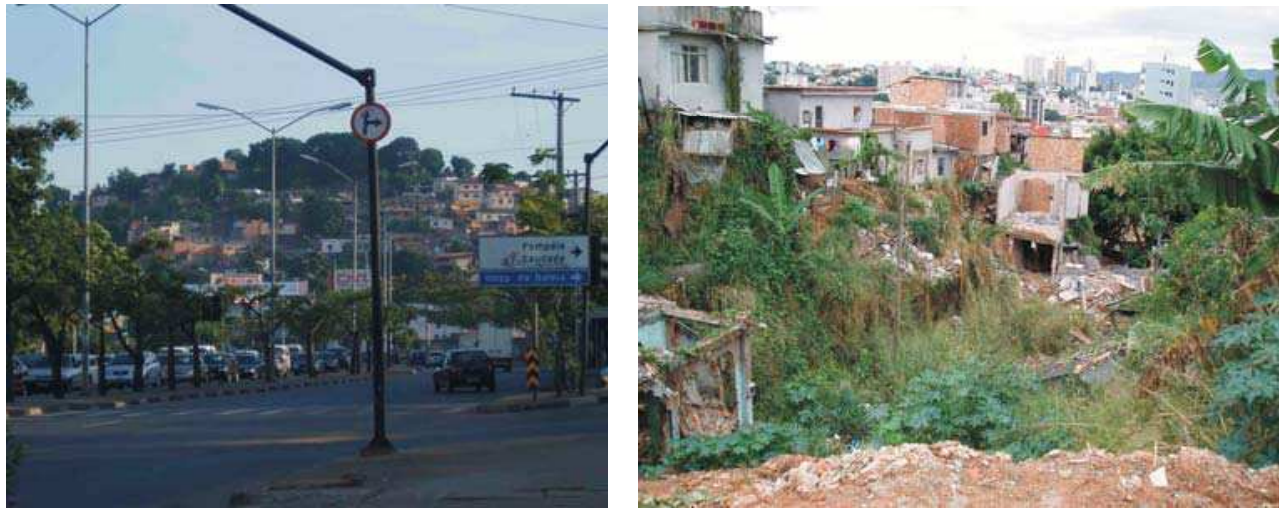

Fig. 7 and 8. Vila Nossa Senhora do Rosário, and Vila Senhor dos Passos
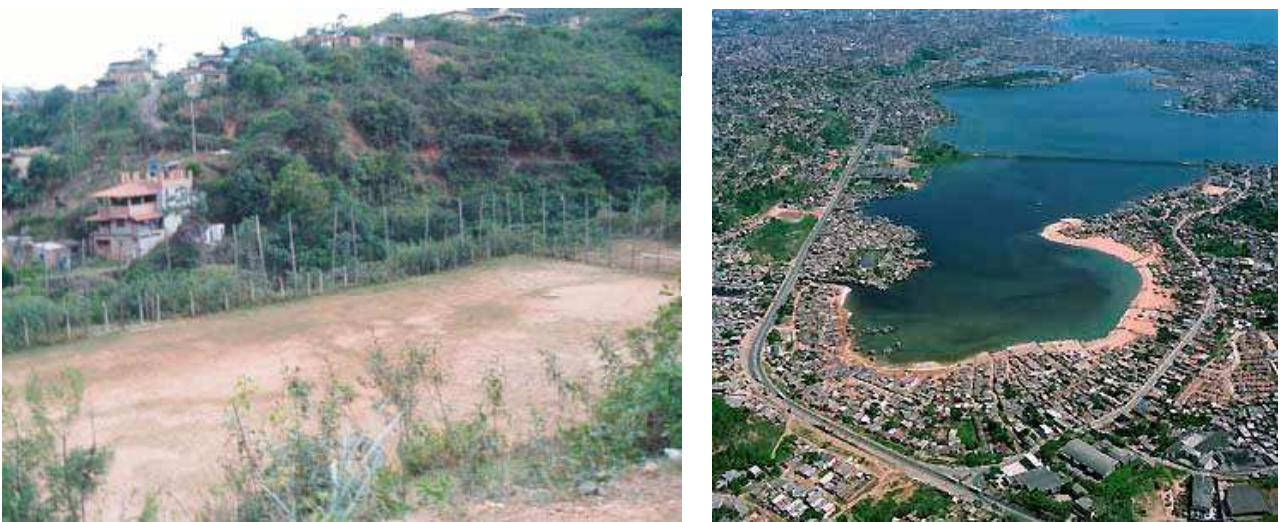

Fig. 9 and 10. Bairro Córrego da Ilha, Sabará (MG), and Group I, Salvador (BA)

The case studies from Bahia are: 
- GROUP I - Boiadeiro, Joanes Centro Oeste, Alagados I and Alagados II, Atlântico (Fig. 10): situated on a slope in the Municipality of Sabará. The intervention is partially complete and began in the 1980s through self-help processes.

- GROUP II - Alagados IV and V(Fig. 11)

- GROUP III - Nova Primavera, Joanes Azul, Araçás I (Fig. 12)
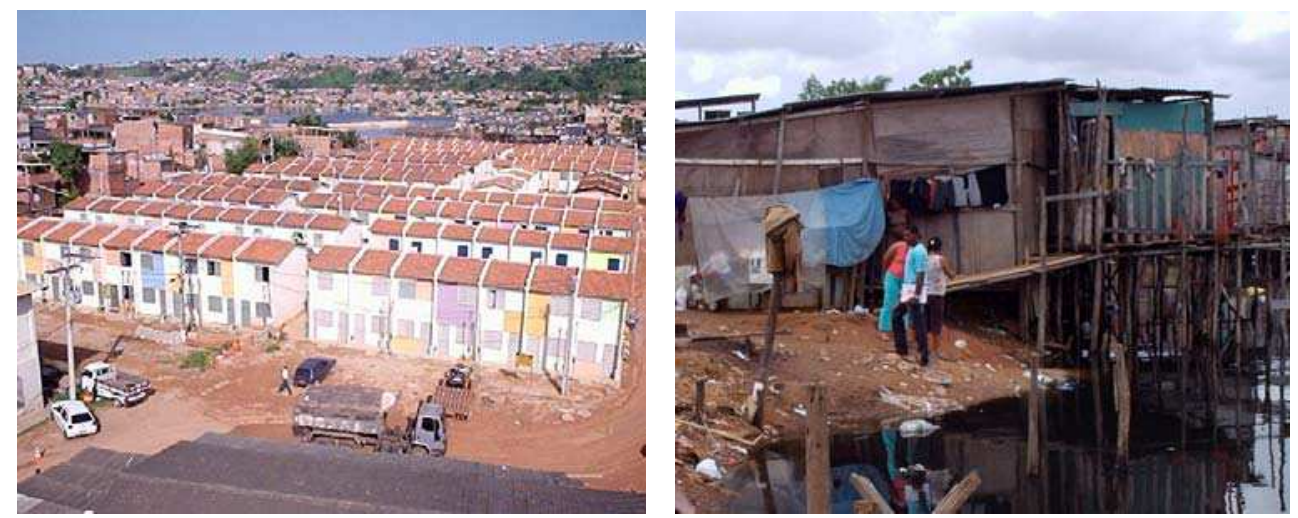

Fig. 11 and 12. Group II, and Group III, Salvador (BA)

\subsection{Analysis of the Components of Urbanisation Costs}

The costs of urbanisation for the case studies were obtained from data provided mostly by the public agencies that promoted the interventions, among others. In the case study of Minas Gerais, Bairro Córrego da Ilha, there was no available information about the costs of the urbanisation projects.

The particularities of each settlement (in terms of differences in its social and physical characteristics) impose different priorities to be given to type of cost component, with variable costs per unit. It is also important to emphasise that cost analysis, in the case of slum upgrading experiences, is difficult, because of the quality of the available data.

This analysis was performed on a comparative way. Table 2 shows an analysis of the data, which were divided into three groups: infrastructure, superstructure, and operational activities, and Table 3 shows the total costs of each urbanisation per family, updated for December 2005.

Comparing the three case studies from São Paulo, it can be seen that the technical constraints of the different communities predominantly influenced their costs. Parque Capuava, from Santo André, had the lowest cost per family, probably because it was developed over a long time, trying to minimise the overall impact on families and to adapt it to the urban structure already in place and to the type of work developed by each household. Another issue that seems to have contributed to its success was the emphasis on monitoring and social development, in addition to the direct participation of many sectors of the municipal government.

The other two interventions from São Paulo, Sete de Setembro and Parque Amélia Santa Margarida, demanded more radical solutions to sanitation, involving plumbing, water courses, and, in one of these cases, a large number of removals. This emphasises that this program - Programa de Saneamento Ambiental da Bacia do Guarapiranga (COBRAPE, 
2001) - primarily aimed to use the urbanisation of slums for a larger goal of fighting economic and environmental problems caused by degraded areas of the basin around the Guarapiranga reservoir. In general, the urbanisation achieved their goals, including obtaining satisfactory rates for the Index of Environmental Health of Urbanised Slums.

\begin{tabular}{|l|l|l|}
\hline \multicolumn{1}{|c|}{ Infrastructure } & \multicolumn{1}{c|}{ Superstructure } & \multicolumn{1}{c|}{ Operational Activities } \\
\hline Road System & Purchase of Areas & Executive Project \\
\hline Network of Supply of Water & $\begin{array}{l}\text { Rental of Areas or } \\
\text { Equipment }\end{array}$ & Construction Management \\
\hline Network of Sewage & $\begin{array}{l}\text { Assembly of Temporary } \\
\text { Accommodation }\end{array}$ & Construction Supervision \\
\hline Network of Drainage & Construction of Homes & Construction Maintenance \\
\hline Containment & Relocating & Technical Advice \\
\hline Network of Electric Energy & Reforms in Affected Houses & Social Assistance \\
\hline Network of Public Lighting & Buildings & Other Items \\
\hline $\begin{array}{l}\text { Areas with Equipment for } \\
\text { Collective Use }\end{array}$ & Demolition & \\
\hline Collection of Garbage & Technical Services & \\
\hline $\begin{array}{l}\text { Urban Furniture and } \\
\text { Signalling }\end{array}$ & & \\
\hline Special Unites & & \\
\hline
\end{tabular}

Table 2. Groups of Components of Costs

\begin{tabular}{|c|c|c|c|c|c|c|}
\hline \multicolumn{2}{|c|}{ State } & Case Study & Infrastructure & Superstructure & $\begin{array}{c}\text { Operational } \\
\text { Activities }\end{array}$ & $\begin{array}{c}\text { Total } \\
\text { (R\$/Family)* }\end{array}$ \\
\hline 1 & \multirow{3}{*}{ SP } & Sete de Setembro & $12,706.00$ & $1,320.48$ & $5,270.25$ & $19,296.73$ \\
\hline 2 & & $\begin{array}{l}\text { Parque Amélia } \\
\text { Santa Margarida }\end{array}$ & $9,604.67$ & $10,992.88$ & $6,156.53$ & $26,754.08$ \\
\hline 3 & & Parque Capuava & $5,509.10$ & $4,683.63$ & $1,105.89$ & $11,298.62$ \\
\hline 4 & \multirow{3}{*}{ RJ } & $\begin{array}{l}\text { Morro da } \\
\text { Providência }\end{array}$ & $8,614.86$ & 820.66 & $1,160.15$ & $10,595.67$ \\
\hline 5 & & Vila Mangueiral & $5,824.04$ & 958.76 & 677.68 & $7,460.48$ \\
\hline 6 & & Vigário Geral & $19,132.49$ & 985.92 & $2,380.16$ & $22,498.57$ \\
\hline 7 & \multirow{3}{*}{ MG } & $\begin{array}{l}\text { Vila Senhor dos } \\
\text { Passos }\end{array}$ & $5,079.77$ & $2,700.06$ & $1,453.47$ & $9,233.30$ \\
\hline 8 & & $\begin{array}{l}\text { Vila Nossa Senhora } \\
\text { do Rosário }\end{array}$ & $3,669.71$ & $8,996.72$ & $1,427.44$ & $14,093.44$ \\
\hline 9 & & $\begin{array}{l}\text { Bairro Córrego da } \\
\text { Ilha }\end{array}$ & - & - & - & - \\
\hline 10 & \multirow{3}{*}{ BA } & Group I & $11,827.01$ & $11,518.45$ & - & $23,345.46$ \\
\hline 11 & & Group II & $7,044.88$ & $2,478.08$ & - & $9,522.96$ \\
\hline 12 & & Group III & $14,771.63$ & $1,150.66$ & - & $15,922.29$ \\
\hline
\end{tabular}

* US\$ 1.00 approx. R\$ 1.50

Table 3. Total Costs of Case Studies 
In the case of Rio de Janeiro, Vigário Geral had the highest cost per family, which can be explained by the large size of the slum and the need for two stages of urbanisation because the value estimated for the first contract was not sufficient to finish the planned work.

In Minas Gerais, the highest costs per family were in Vila Nossa Senhora do Rosário, perhaps because the costs provided to the urbanisation of Vila Senhor dos Passos are related only to one type of program (in this case, the urbanisation was provided by two different programs: Habitar-Brasil and Alvorada, and the costs related to the latter were not available). The two communities have similar physical characteristics; however, Vila Senhor dos Passos has a greater aerial extent than Vila Nossa Senhora do Rosário.

\subsection{Analysis of the Index of Environmental Health of Urbanised Slums}

The Index of Environmental Health for Urbanised Slums is defined by fourteen indicators and aims to measure, in an individualised way, the elements that interfere with the functionality of existing actions in the slum. After scoring them on a scale from 0 to 100, these indicators are grouped in the calculation of an average for the Index. Urban slums are considered to have good health when they have a score above 85 , moderate health when the score is between 70 and 85 , and poor health when the score is less than 70 . The final score may be used as a reference for the ranking of slums, which allows to the characterisation of the level of need among different slums in the same municipality.

In the case of this research, the analysis using the Index was done by comparing only those cases where the urbanisation process had already been finalised, which include the three cases from Rio de Janeiro, Morro da Providência, Vila Mangueiral and Vigário Geral, and the two cases from São Paulo, Sete de Setembro and Parque Amélia Santa Margarida. As the integrated data analysis depends on the integrity of the survey, the absence of some data may interfere in the conclusions, causing possible misinterpretations. Table 4 shows the scores related to the five case studies.

\begin{tabular}{|c|c|c|c|c|c|c|c|c|c|c|c|c|c|c|c|}
\hline \multirow[b]{2}{*}{ Case Study } & \multicolumn{14}{|c|}{ INDICATORS } & \multirow[b]{2}{*}{ 㸚 } \\
\hline & 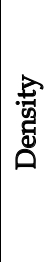 & 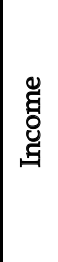 & 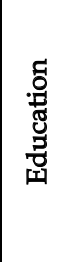 & 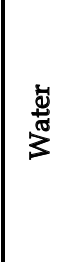 & 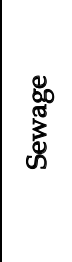 & 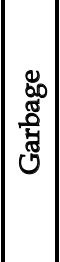 & 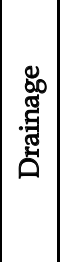 & 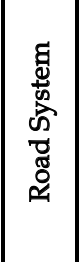 & $\begin{array}{l}\overrightarrow{0} \\
0 \\
0 \\
8 \\
0\end{array}$ & 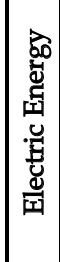 & 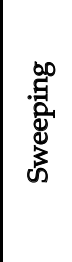 & 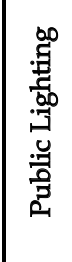 & 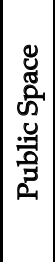 & 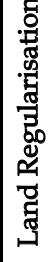 & \\
\hline Sete de Setembro & 80 & 20.1 & 0 & 100 & 100 & 100 & 90.3 & 82.85 & 100 & 100 & 93.33 & 49.7 & 60 & 80 & 79.26 \\
\hline $\begin{array}{l}\text { Parque Amélia / } \\
\text { Santa Margarida }\end{array}$ & 80 & 9.9 & 0 & 100 & 100 & 100 & 90.6 & 70.01 & 100 & 100 & 76.68 & 41.71 & 100 & 80 & 78.74 \\
\hline Morro da Providência & 80 & 79 & 67 & 90.06 & 90 & 90 & 90 & 29.18 & 100 & 90 & 100 & 100 & 60 & 80 & 81.87 \\
\hline Vila Mangueiral & 80 & 79 & 80.20 & 90.22 & 90.22 & 90 & 90 & 65.2 & 100 & 100 & 100 & 100 & 100 & 80 & 88.98 \\
\hline Vigário Geral & 100 & 23 & 67 & 90 & 90 & 90 & 90 & 64.24 & 100 & 100 & 100 & 100 & 100 & 80 & 85.31 \\
\hline
\end{tabular}

Table 4. Index of Environmental Health of Urbanised Slums 
Only two of the cases from Rio de Janeiro, Vila Mangueiral and Vigário Geral, had positive scores. Morro da Providência, also in Rio de Janeiro, was classified as moderate. The two cases from Sao Paulo, Sete de Setembro and Parque Amélia Santa Margarida, have moderate scores with very similar values. The majority of the cases are in a favourable situation, but the indicators of income, education, traffic routes, public lighting, and public space are, for the most part, classified as unsatisfactory.

\subsection{Post-Occupation Diagnosis}

Here, the main results of the post-occupation diagnoses, made through information obtained from the respective public institutions that promoted the urbanisation processes, are presented.

\section{If the defined objectives and results were achieved}

At the time of this study, $100 \%$ of the water supply and sanitation networks and all geotechnical services and road systems had already been implemented in Parque Capuava (Santo André, Sao Paulo); the electric grid, street lighting, and garbage collection system had not yet been completed. According to the technical explanations, the deployment of these services is the last stage of urbanisation. In the cases of Sete de Setembro and Parque Amélia Santa Margarida, the goals and results defined by the Environmental Sanitation Program of the Guarapiranga Watershed (the program that promoted the urbanisation of these slums) were completely achieved.

In the three case studies from Rio de Janeiro, the objectives defined in the projects and results had been achieved.

In Minas Gerais, the process of urbanisation had not been fully completed at the time of this research. At Vila Senhor dos Passos, where the urbanisation process is more advanced, the goals and results had been achieved.

In Bahia, the works were still in progress in some cases (Alagados IV and V, Joanes Blue, for example), and there was no post-occupation diagnosis.

If the physical and environmental improvements were made

In all cases where this analysis could be done, it was determined that the physical and environmental improvements, as far as possible, met the main needs of the communities.

If there were enough resources to carry out all the steps planned

In the cases of Minas Gerais, Rio de Janeiro, and Bahia, there were situations where the resources were inadequate, most often causing delays in the urbanisation process. In the case of São Paulo, despite the fact that there had been delays in the release of funds, resources were considered sufficient for the steps envisaged.

\section{If there were social projects to generate employment and income}

In most cases, projects to generate employment and income had been carried out, except for Bairro Córrego da Ilha (Sabará, Minas Gerais) and Sete de Setembro and Parque Amélia Santa Margarida (São Paulo).

In Parque Capuava (Santo André, São Paulo), several social projects were also deployed during the intervention.

In Rio de Janeiro, at the time of the works in Vigário Geral, there was a co-operative of cleaning services and works. In Vila Mangueiral, there were social projects linked to the Secretary of Social Assistance.

In Minas Gerais, due to the large problems related to the generation of income in the slums, programs and actions aimed at expanding the job training were developed, and, 
consequently, there were increased employment opportunities and an improvement in incomes.

In Salvador, there was an integration of urban interventions with actions that stimulate socio-economic practices, linking the physical interventions to social actions and income generation, such as training courses about the formation of co-operatives (preparation of status, legal proceedings legal, etc.), creation and deployment of a soap factory, a project of sports and recreation for young people, expansion of services and programs of basic health, training of community health agents, support for the creation of nurseries, and improvement of programs and services for reducing unemployment and increasing income.

If there had been some research about users' satisfaction and/or evaluation of the correlation between the project and the interventions implemented

There had been some research in Vila Senhor dos Passos (Minas Gerais), in the cases from Sao Paulo and from Rio de Janeiro. The cases of Bahia did not have such research.

If there were social work involvement with the community after the completion of the projects

In all cases except for Bairro Córrego da Ilha (Sabará, Minas Gerais), there had been social work involvement with the community after the completion of the projects. This work was linked to social projects to generate employment and income, health education projects, environmental projects, and leisure and health activities.

In Parque Capuava (Santo André, São Paulo), more social work activities are scheduled for after the completion of the project. Plans have already been developed for leisure, sport, health, and environmental education programs, with visits to parks and water treatment plants. In addition, a council of representatives was established for each sector (3 persons for each of the 6 sectors), including officials from various community programs developed by the Municipality.

In the cases from Rio de Janeiro, several social projects were implemented, which were linked to education, professional training, Information Technology, and other areas.

At Vila Nossa senhora do Rosário (Minas Gerais), the urbanisation process was ongoing and was in a less advanced stage than at Vila Senhor dos Passos, where the social project was planned and was being implemented. Removals at any stage of deployment were preceded by social actions.

In Bahia, social activities continued during the post-occupation and included community agents, co-operatives, and schools.

Mechanisms of control to ensure the sustainability of the goals and achievements

In Parque Capuava (Santo André, São Paulo), the sustainability of the goals and achievements was to be ensured by community monitoring through the Programme of Community Health Agents.

In Rio de Janeiro, Urban and Social Guidance Agencies (POUSO) were installed in the communities in the final stage of work, integrated with teams of architects, engineers, social workers, and community agents who act by educating residents on the importance of preserving public spaces and the equipment deployed. The teams represent the presence of the Municipality in these localities. Moreover, the POUSO developed a town planning legislation for these communities. In order to ensure the presence of public power in the communities, the POUSO has the function of co-ordinating with agencies that are responsible for the collection of garbage, the installation and maintenance of power and water supply networks, and other public services. The POUSO team guided new 
construction to ensure that it is made in public areas or places of risk, thereby maintaining the alignment of streets. The work of the technicians also aims to prevent the growth of slums.

In Minas Gerais, in Vila Senhor dos Passos, actions to minimise risks had been taken, such as maintaining and intensifying the permanent training of leaders, seeking to integrate new representatives into the group of reference, stimulating the expansion of areas of participation and commitment with the community from its residents, and strengthening the organisational foundations of the community. Moreover, there were actions related to health education and training of community agents to stimulate other people to participate of sustainable issues. Regarding the financial sustainability of families, other actions were also taken, usually linked to programs to generate income.

In Bahia, the activities of the Social Sector of CONDER worked during the post-occupation with community agents, aiming to strengthen the creation of employment and income of the populations in these communities.

\section{Conclusions}

From the integrated analysis of the research, several conclusions can be made. The main findings from the set of experiences of urbanisation in the case studies are highlighted below.

- The interventions that were developed through programs of urbanisation have been more successful than those that did not have guidelines to be followed.

- The main objective of the programs was generally linked to the improvement or construction of major urban structures in slums, with actions related to social development in a sustainable way, with the potential for community and social integration.

- The programs, in general, can be considered systematic, and it is recommended to avoid isolated actions in a dense urban structure, which may result in inadequate consolidation of facilities.

- All the programs studied were applied to several settlements with different physical and social characteristics. Furthermore, the employment of the same program in various situations allowed it to be improved, and the improvements were applied in later applications.

- The documentation process for completion of the program is important in order to direct the actions to be undertaken. It is necessary to establish responsibilities and procedures of the elements involved.

- In both Rio de Janeiro and Minas Gerais, municipal bodies responsible for the housing sector were created. The decision to establish a technical and administrative group (SMH and URBEL) that incorporated the previous experience of the administrative staff has proved to be extremely fruitful, and it is a fundamental condition for the success of interventions in any public sector of activity.

- In the planning of the projects, the methodologies used in the programs are quite similar. They were developed in an integrated manner involving various departments, and they manage the integration and urban impact, degree of consolidation, state land, health, and geotechnical risks, among other issues. 
- The proposed interventions have an integrated and multisectoral nature, presenting the solution of physical, biotic, and anthropic problems. This type of action is therefore of fundamental importance in order to improve environmental conditions of the area and the quality of life.

- In all programs of urbanisation, socio-economic profiles of the communities were drawn up.

- In all programs of urbanisation, the removal and resettlement of housing units is expected when necessary. There is the possibility of working with the population and facilitating the negotiation process; however, studies are needed to address the feasibility of such resettlement.

- The government is the project manager in all programs of urbanisation, and, in most cases, the projects are carried out by specialised companies contracted through bidding.

- A system of monitoring and evaluating projects was designed for only some of the cases.

- The licensing of projects, which involves the examination and approval of projects, was done in most programs of urbanisation, either by municipal and state institutions, but also by other areas of the government.

- In all cases, the public resources were combined with other donors. In the programs studied, the resources were linked to the IDB (Inter-American Development Bank), its local counterpart, the IBRD (International Bank for Reconstruction and Development), and the Participatory Budget, MAE (Ministry of Foreign Affairs of Italy).

- In almost all programs of urbanisation, the institutions used the outsourcing of services, projects, and works as a basic standard through the bidding process.

- Clearly, the guidelines were continually improved in cases where it is possible to monitor the operations.

- It is important to emphasise the important role played by urban regularisation in the transformation of the citizenship conditions of the population.

- There were problems related to the final approval of houses since most of the buildings in these settlements have been built illegally, with no approval from the local government.

\section{References}

Abiko, A. K. \& Almeida, M. A. P. (2000). Indicadores de Salubridade Ambiental em Favelas Localizadas em Áreas de Proteção aos Mananciais: o Caso da Favela Jardim Floresta. Boletim Técnico da Escola Politécnica da USP, São Paulo, 32 p.

Almeida, M. A. P. (1999). Indicadores de Salubridade Ambiental em Favelas Urbanizadas. O Caso de Favelas em Áreas de Proteção Ambiental. D.Sc. Thesis, Escola Politécnica da Universidade de São Paulo, Dep. de Engenharia de Construção Civil, 226 p.

Bassul, J. R. (2005). Estatuto da Cidade: Quem Ganhou? Quem Perdeu? Senado Federal, Subsecretaria de Edições Técnicas, Brasília

COBRAPE (2001). Programa de Saneamento Ambiental da Bacia do Guarapiranga. Companhia Brasileira de Projetos e Empreendimentos, São Paulo

Conde, L. P. \& Magalhães, S. (2004). Favela-Bairro: Uma Outra História da Cidade do Rio de Janeiro: 1993/2000. Uma Ação Urbanizadora para o Rio de Janeiro. Vivercidades, Rio de Janeiro, $157 \mathrm{p}$. 
Denaldi, R. (2003). Política de Urbanização de Favelas: Evolução e Impasses. D.Sc. Thesis, Faculdade de Arquitetura e Urbanismo, Universidade de São Paulo

FINEP (2007). Projeto Refavela. Relatório Final, MCT

Lareau, S. (2005). Método para Estimativa de Custos de Infra-Estrutura em Urbanização de Favelas no Município de São Paulo. M.Sc. Dissertation, Instituto de Pesquisas Tecnológicas do Estado de São Paulo

Santos, C. N. F. (1977). Volviendo a Pensar em Favelas a Causa de Las Periferias. Nueva Sociedad, Caracas

Turner, J. F. C. (1972). Una Nueva Visión del Déficit de Vivienda. In: Lewis, D., EI Crescimiento de las Ciudades, Gustavo Gilli, Madrid

URBEL (2002). Plano Global Específico: Vila Nossa Senhora do Rosário. Compania Urbanizadora de Belo Horizonte, Belo Horizonte 


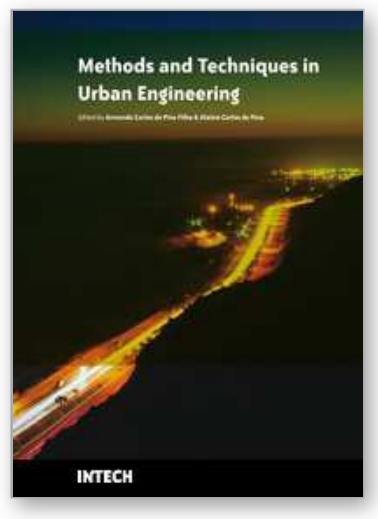

\author{
Methods and Techniques in Urban Engineering \\ Edited by Armando Carlos de Pina Filho and Aloisio Carlos de Pina
}

ISBN 978-953-307-096-4

Hard cover, 262 pages

Publisher InTech

Published online 01, May, 2010

Published in print edition May, 2010

A series of urban problems such as dwelling deficit, infrastructure problems, inefficient services, environmental pollution, etc. can be observed in many countries. Urban Engineering searches solutions for these problems using a conjoined system of planning, management and technology. A great deal of research is devoted to application of instruments, methodologies and tools for monitoring and acquisition of data, based on the factual experience and computational modeling. The objective of the book was to present works related to urban automation, geographic information systems (GIS), analysis, monitoring and management of urban noise, floods and transports, information technology applied to the cities, tools for urban simulation, social monitoring and control of urban policies, sustainability, etc., demonstrating methods and techniques applied in Urban Engineering. Considering all the interesting information presented, the book can offer some aid in creating new research, as well as incite the interest of people for this area of study, since Urban Engineering is fundamental for city development.

\title{
How to reference
}

In order to correctly reference this scholarly work, feel free to copy and paste the following:

Adauto Lucio Cardoso, Angela Maria Gabriella Rossi (2010). Experiences with the Urbanisation of Slums: Management and Intervention Models, Methods and Techniques in Urban Engineering, Armando Carlos de Pina Filho and Aloisio Carlos de Pina (Ed.), ISBN: 978-953-307-096-4, InTech, Available from: http://www.intechopen.com/books/methods-and-techniques-in-urban-engineering/experiences-with-theurbanisation-of-slums-management-and-intervention-models

\section{INTECH}

open science | open minds

\section{InTech Europe}

University Campus STeP Ri

Slavka Krautzeka 83/A

51000 Rijeka, Croatia

Phone: +385 (51) 770447

Fax: +385 (51) 686166

www.intechopen.com

\section{InTech China}

Unit 405, Office Block, Hotel Equatorial Shanghai

No.65, Yan An Road (West), Shanghai, 200040, China 中国上海市延安西路65号上海国际贵都大饭店办公楼 405 单元

Phone: +86-21-62489820

Fax: +86-21-62489821 
(C) 2010 The Author(s). Licensee IntechOpen. This chapter is distributed under the terms of the Creative Commons Attribution-NonCommercialShareAlike-3.0 License, which permits use, distribution and reproduction for non-commercial purposes, provided the original is properly cited and derivative works building on this content are distributed under the same license. 